\title{
Diet of two insectivorous fish species in a Brazilian semiarid reservoir
}

Jean Carlos Dantas de Oliveira - Jônnata Fernandes de Oliveira •

Luzia Geize Fernandes Rebouças • José Luís Costa Novaes •

Rogério Taygra Vasconcelos Fernandes • Danielle Peretti

JCD Oliveira (Corresponding author) - LGF Rebouças • JLC Novaes - RTV Fernandes

Universidade Federal Rural do Semi-Árido (UFERSA), Centro de Ciências Biológicas e da Saúde, BR 110 - Km 47, Bairro Costa e Silva, 59625-900, Mossoró, RN, Brazil.

email: jeancarlosdo@hotmail.com

\section{JF Oliveira}

Instituto Federal de Educação, Ciência e Tecnologia do Maranhão (IFMA), Campus Avançado Carolina, Praça do Estudante, s/n, Centro, 65980-000, Carolina, MA, Brazil.

\author{
D Peretti \\ Universidade do Estado do Rio Grande do Norte (UERN), \\ Departamento de Ciências Biológicas, Av. Prof. Antônio \\ Campos s/n, Bairro Costa e Silva, 59625-620, Mossoró, RN, \\ Brazil.
}

Received: July 27, 2018 • Revised: September 05, 2018 • Accepted: September 26, 2018

Abstract Long periods of aridity can cause changes in the diet of fish since hydrological variations affect the availability of food resources. The objective of this study was to investigate the diet of two species of fish (Astyanax aff. bimaculatus and Triportheus signatus), present in the Umari reservoir in Upanema, Rio Grande do Norte, Brazil, to evaluate the influence of seasonality on their diets. The samples were collected quarterly during the months of February to November 2013, with four days in the field, and at five different sites of the reservoir with nets with meshes ranging from 12 to $70 \mathrm{~mm}$ (between adjacent nodes). For the identified items in the diet, the frequencies of occurrence and volume, combined in the calculation of the Alimentary Index (IAi), were obtained. Significant alterations in the diet of the species were observed, predominantly in insects. The changes found in the diet indicate an influence of seasonality on the feeding habits of these species, with a predominance of autochthonous items in the dry period and allochthonous items in the rainy period.

Keywords: feeding, hydrological cycle, northeast, weir

\section{Introduction}

Studies on feeding in fish are some of the most important investigations for understanding the biology of fish species by making it possible to know the diet and the ways in which the individuals explore the alimentary resources within communities (Oliveira et al 2018). Research on natural nutrition has provided relevant information on the functioning of the ecosystem in which fishes live. It allows for the understanding of the ecology of the species, their role in the ecosystem, and the identification of the factors that determine the pattern of feeding of fish throughout their life cycle
(Oliveira et al 2016a). This knowledge is fundamental for the conservation of ecosystems (Pessoa et al 2012), especially in the semiarid regions of northeast Brazil. These regions are characterized by long periods of drought, a factor that affects food availability and causes changes in fish diet (Santos et al 2014) in different seasons of the year (Silva et al 2012a).

Another important factor in the dynamics of natural fish feeding is the reservoirs built in semiarid regions of the Brazilian northeast, the primary functional objective of which is to avoid water shortage periods (Vieira et al 2010). However, the main effect of the reservoirs is a change in the natural flow regime, which, coupled with the fact that the semiarid regions of the Brazilian northeast suffer a major deficiency in water resources, may lead to a change in the availability of food resources and their use by fish (Abujanra et al 2009; Hahn and Fugi 2009). In addition, the diet of fish can be altered when fish explore a new region in the environment (Gandini et al 2014). There are spatial and seasonal changes in habitat, considering different locations and periods have different abiotic and biotic conditions (Abelha, Agostinho and Goulart 2001), and the fish may behave opportunistically, substituting scarce food items with abundant ones (Davies et al 2008).

It is worth noting that due to seasonal variation in the tropics, tropical fish exhibit intense trophic plasticity in their diets (Montenegro et al 2011). Freshwater fish have a wide range of food strategies and tactics, consuming many items and exhibiting adaptations to new imposed conditions (Hahn and Fugi 2007) in which they can improve their diet by using the most energetic resources or through consuming the food items that are in greater availability (Macarthur and Pianka 1966). These changes in diet are predictable and gradual, but abrupt changes in the environment such as those caused by the 
construction of dams on rivers (Hahn and Fugi 2009) and by oscillations in the volume of water in the reservoirs (Petry et al 2013) are unpredictable, and only species with higher food plasticity are adapted for these changes (Hahn and Fugi 2007).

Although reservoirs are highly economically important environments, there are few studies about their ecological importance, concerning both the structure and function of these environments, or about fish assemblages, mainly referring to Brazilian northeastern species, and especially in regards to their diet. Considering that in the semiarid regions of northeast Brazil, low annual precipitation affects fish trophic guilds (Oliveira et al 2016a; Oliveira et al 2016b) and the need to understand the underlying processes, the objective of this study was to investigate the diet of two species of fish, Astyanax aff. bimaculatus (Linnaeus, 1758) and Triportheus signatus (Garman, 1890), all of which are of ecological and economic interest and are present in the Umari reservoir, Upanema, Rio Grande do Norte, Brazil, in an effort to determine the influence of seasonality on the feeding of these species. The hypothesis was that rainfall results in changes in the available food resources over time.

\section{Materials and Methods}

Study area

The Senador Jessé Pinto Freire dam $\left(5^{\circ} 38^{\prime} 31\right.$ "S; $37^{\circ} 15^{\prime} 28^{\prime \prime} \mathrm{W}$ ), known popularly as the Umari dam, was completed in 2002, through the blockade of th Carmo River, belonging to the hydrographic basin of the Apodi-Mossoró
River, which represents the largest genuinely Potiguar basin. Located $8 \mathrm{~km}$ upstream from the Upanema municipality, in the western Potiguar mesoregion and the Midwest microregion, the Umari dam has the third largest reservoir capacity in the state, with approximately $300,000.000 \mathrm{~m}^{3}$ (SEMARH 2013).

\section{Sampling and procedures with specimens collected}

The collections occurred in five sites (Figure 1) distributed throughout the body of water, quarterly, between February and November of 2013, with four days in the field. At each site, sampling was performed with the same sampling effort, composed of eleven gill nets with the following meshes: $12,15,20,25,30,35,40,45,50,60$ and $70 \mathrm{~mm}$ (between knots adjacent), measuring $15 \mathrm{~m}$ in length and $2.0 \mathrm{~m}$ in height. The fishing apparatus were set up at dusk (05:00 p.m.) parallel to the margins and remained for a period of 12 hours, until dawn (05:00 a.m.). The captured specimens were screened and identified, and their stomachs were removed for analysis of food items.

During the sampling period, variation in precipitation was recorded, with the highest value observed in April 2013 (252 mm). In the months of August, September and October, rainfall was not recorded (Figure 2). Regarding the water volume of the reservoir, changes were also observed, with the highest values during the months of May and June, and the lowest values during the months of March and April 2013 (Figure 2).

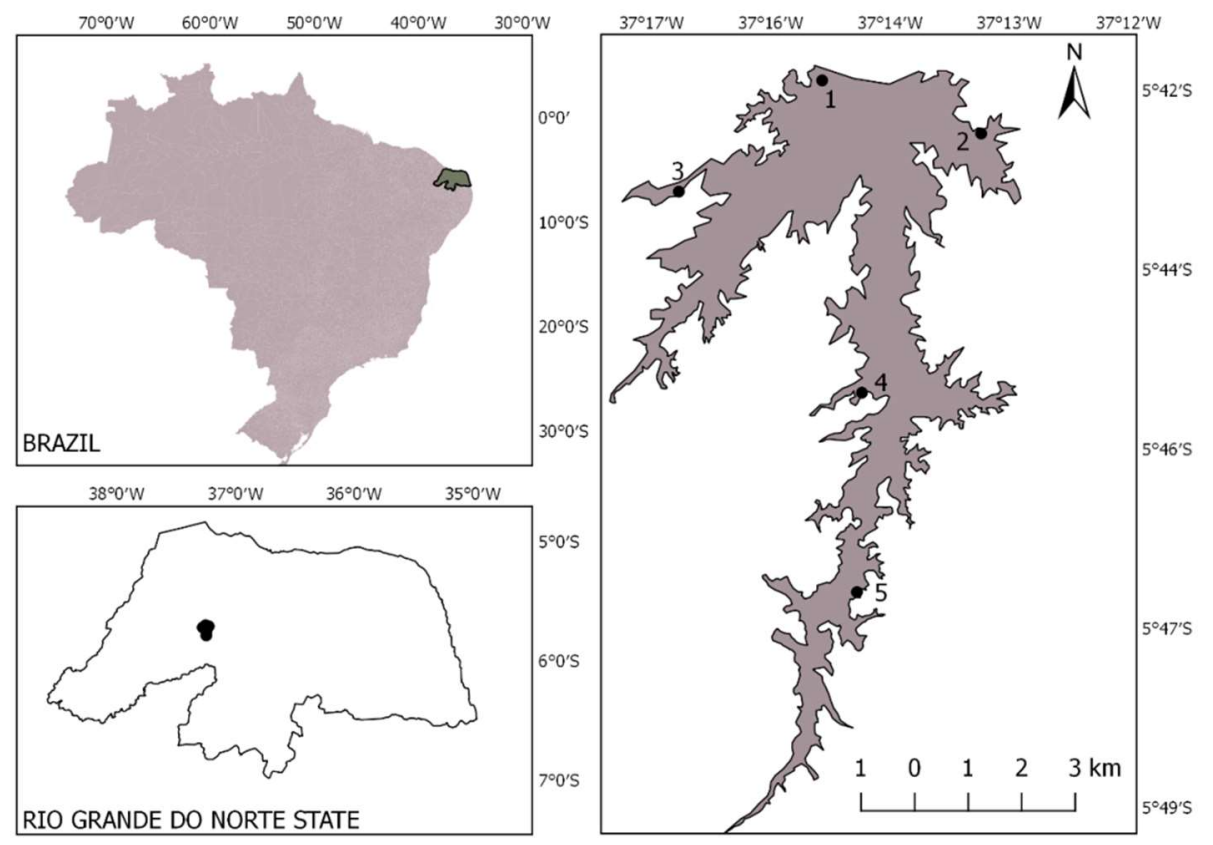

Figure 1 Location of the collection sites of fish on the Umari reservoir, the hydrographic basin of the Apodi-Mossoró River, Rio Grande do Norte, Brazil. 


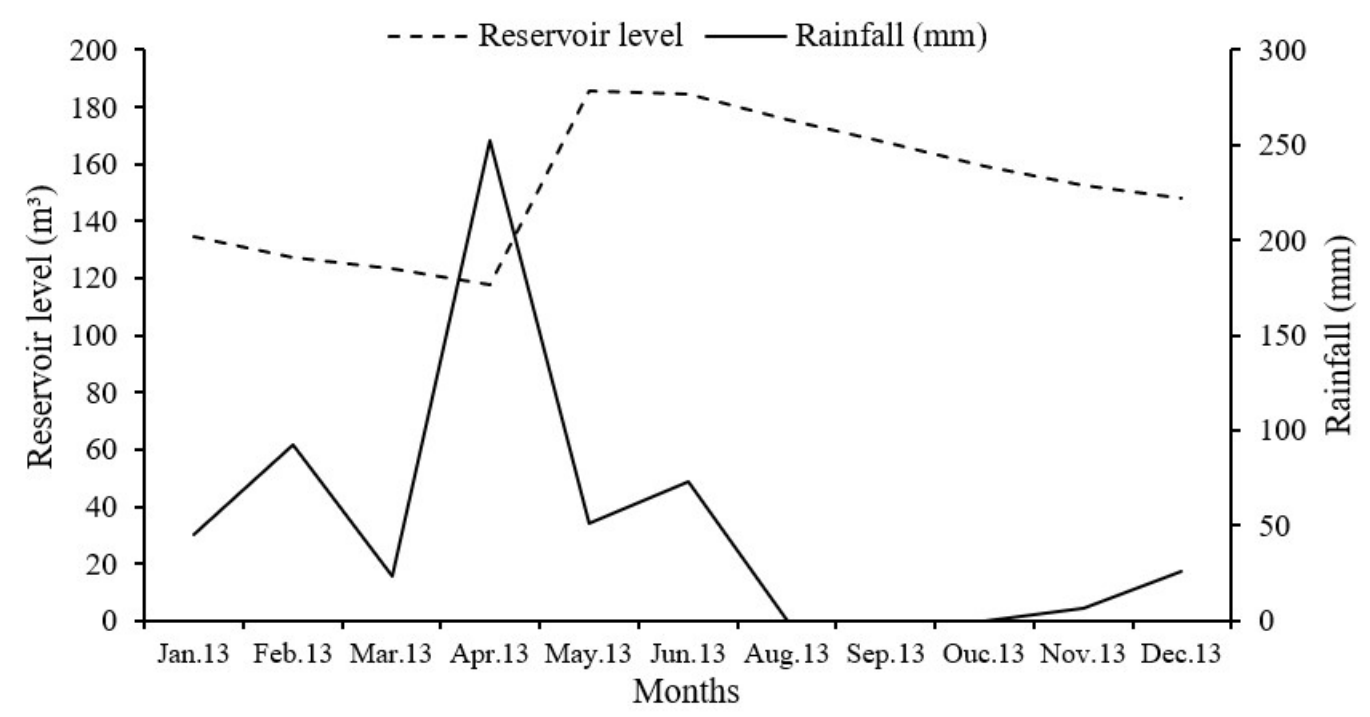

Figure 2 Monthly rainfall measurements for Upanema municipality and the Umari reservoir, Rio Grande do Norte state, during the study period.

\section{Food content analysis}

Food items were identified at the lowest taxonomic level using stereoscopic and optical microscopes and the help of specialized literature (McCafferty 1981; Needham and Needham 1982; Merritt and Cummins 1996). The volume of the identified food items was obtained following two procedures according to the type and size of the food: i) through beakers whose volume is given by the displacement of liquid (Hynes 1950; Hyslop 1980; Zavala-Camin 1996) and by a ii) petri dish method (Hellawell and Abel 1971). From the diet data, the occurrence frequencies and percent volume were obtained (Hynes 1950; Hyslop 1980; Rosecchi and Nouaze 1987; Zavala-Camin 1996). The association of the frequencies gave rise to the calculation of the Alimentary Index (IAi) (Kawakami and Vazzoler 1980), presented in percentage values.

To evaluate food item preferences and determine the dietary habits of each species, the following scale was used (Rosecchi and Nouaze 1987), where: IAi $>50 \%$ - preferential item; $25<\mathrm{IAi}<50 \%$ - secondary item; IAi $<25 \%$ - accessory item.

The Alimentary Index (IAi) values of the species were used to establish the diet preference items per sampling period. The global diet was also explored through the graphical analysis proposed by Costello (1990). This consists of a twodimensional graph, which shows the contribution in percentage of occurrence (x-axis) and percentage of volume (y-axis) of food groups. The data were analyzed in the statistical program Paleontological Statistics - PAST, version 3.15 (Hammer et al 2018).

\section{Results}

A total of 214 individuals (Astyanax aff. bimaculatus, $\mathrm{n}=169$ and Triportheus signatus, $\mathrm{n}=45$ ) were captured, 78 of which had their stomachs analyzed (A. aff. bimaculatus, $\mathrm{n}$ $=44$ and $T$. signatus, $\mathrm{n}=34)($ Table 1$)$.

From the analyzed stomachs, 15 food items were identified in three main categories. Animal items constituted the highest number of taxa, and included the following orders of insects: Hymenoptera, Odonata, Coleoptera, Diptera, Ephemeroptera, Hemiptera, Lepidoptera, Orthoptera and Trichoptera. Also recorded were shrimp, arachnids (scorpion and spider), mollusks, microcrustaceans (Conchostraca) and fish scales. The items of plant origin were rest of leaves, stem, seeds, fruits and bark (Table 2).

The predominance of insects (Figure 3), mainly Coleoptera, Dipterans and Odonata, in the diet of the species Astyanax aff. bimaculatus and Triportheus signatus led to the classification of these species as insectivorous. Astyanax aff. bimaculatus also consumed fish scales, digested material and plant material in significant concentrations.

\section{Discussion}

The species Astyanax aff. bimaculatus and Triportheus signatus showed an insectivorous feeding habit, with predominance of Coleoptera, Hymenoptera, Odonata and Diptera in their diets, in addition to other orders of insects such as Ephemeroptera, Hemiptera, Lepidoptera, Orthoptera and Trichoptera. However, the observation of the consumption of shrimp, arachnids, mollusks, microcrustaceans, fish scales and plant material, show a certain plasticity in their eating habits, as well as a flexibility in the search for food resources. 
Table 1 Species, number of individuals collected $(\mathrm{N})$, the percentage of individuals collected $(\% \mathrm{~N})$ number of individuals analyzed (NA) and percentage of individuals analyzed (\% NA), of the two species of fish caught in the Umari reservoir, Rio Grande do Norte, Brazil, between February and November 2013.

\begin{tabular}{lcccc}
\multicolumn{1}{c}{ Species } & $\mathbf{N}$ & $\mathbf{\% N}$ & NA & \%NA \\
\hline Astyanax aff. bimaculatus (Linnaeus, 1758) & 169 & 79.10 & 44 & 56.00 \\
Triportheus signatus (Garman, 1890) & 45 & 21.00 & 34 & 44.00 \\
\hline Total & 214 & 100.00 & 78 & 100.00 \\
\hline
\end{tabular}

Table 2 Alimentary Index (IAi) of the two fish species (Astyanax aff. bimaculatus and Triportheus signatus) studied from the Umari reservoir, Rio Grande do Norte, Brazil, between February and November 2013. C. $1=$ collection 1, C. $2=$ collection 2, C. $3=$ collection 3, C. $4=$ collection 4, with emphasis on the preferences of the species, according to scale Rosecchi and Nouaze (1987). $1=$ autochthonous items; $2=$ allochthonous items; \# = unidentified item.

\begin{tabular}{|c|c|c|c|c|c|c|c|c|c|}
\hline \multirow{2}{*}{$\begin{array}{l}\text { Species } \\
\text { Items }\end{array}$} & & \multicolumn{4}{|c|}{ A. bimaculatus } & \multicolumn{4}{|c|}{ T. signatus } \\
\hline & & C.1 & C.2 & C.3 & C. 4 & C.1 & C. 2 & C.3 & C.4 \\
\hline Shrimp & 1 & & & 0.05 & & & & 0.16 & \\
\hline Coleoptera & 1 & 0.80 & & *79.69 & *50.42 & 0.16 & 0.76 & $* 63.34$ & \\
\hline Hymenoptera & 2 & 1.60 & & 0.27 & & 15.18 & 0.76 & & \\
\hline Mollusks & 1 & & & & 3.94 & 2.15 & & & \\
\hline Odonata & 1 & 2.40 & & & 3.12 & $* 80.61$ & & 0.04 & \\
\hline Plant & $\#$ & 1.26 & & 5.50 & 0.67 & 1.61 & & 0.25 & \\
\hline Digested material & \# & & & 10.04 & 16.70 & & & 1.50 & \\
\hline Diptera & 1 & *70.96 & & & 0.08 & 0.03 & $* 71.23$ & 34.08 & \\
\hline Ephemenoptera & 1 & & & & & & 1.52 & & \\
\hline Hemiptera & 1 & & & 2.51 & & & 0.76 & 0.60 & \\
\hline Trichoptera & 1 & 1.47 & & & 20.39 & & & & \\
\hline Lepidoptera & 2 & 6.68 & & & & & & & \\
\hline Microcrustaceans & 1 & 13.33 & & 0.09 & 4.41 & 0.23 & 24.55 & 0.01 & \\
\hline Arachnids & 2 & 1.47 & & 1.15 & & & & & \\
\hline Fish scales & 1 & & & 0.67 & 0.23 & & & & \\
\hline
\end{tabular}

According to Abelha, Agostinho and Goulart (2001) a high number of species of freshwater fish in Neotropical regions explore different types of food, indicating that this of eating habit is a common adaptation of this ichthyofaunal group (Agostinho et al 2007). This adaptation is evident in reservoirs, environments that are subject to changes resulting from modification of the original natural environment from river to lake, in which species with greater food plasticity are more successful in colonization and exploitation of the various food resources available (Hahn and Fugi 2007).

Feeding flexibility is an important characteristic particularly for freshwater Neotropical fish species (González-Bergonzoni et al 2012). With a variety of food in the tropics, a flexible diet may be associated with the environmental conditions of this aquatic ecosystem (Lopes et al 2014) and may be influenced directly by soil characteristics, vegetation, human activities in drainage systems, and precipitation (Manna et al 2012; XU et al 2012). Thus, changes in the consumption of food items by the species during the study period may have occurred due to the irregularities of the hydrological cycle of the semiarid region of northeast Brazil, which presents extremes of floods and droughts, characteristics that may influence the availability of food resources for fish.

Although most of the fish fauna in tropical reservoirs are supported by resources originating from the aquatic environment (Araújo-Lima et al 1995), studies have pointed out the importance of allochthonous food sources for fish, originating mainly from marginal areas of reservoirs, such as riparian forests (Araújo et al 2005; Silva et al 2014). In addition to spatiotemporal variations in food availability, these sources strongly modify fish foraging behavior (Lopes et al 2011; Lopes et al 2016; Medeiros 2014), which may be a consequence of the hydrological regime of the reservoirs (Abelha et al 2001).

Periods of rainfall increase the reservoir volume, flood extensive swaths of land and expand seasonally the aquatic environment, with flooding along the margins widening the foraging area (Tófoli et al 2010) and allowing the incorporation of allochthonous organisms such as insects 
(Lopes et al 2014) and other terrestrial invertebrates into the aquatic environment (Bonato et al 2012). The opposite occurs in the dry season, with the reduction of the reservoir volume. In this period, there is also an increase in temperature and water transparency values, which favor a higher productivity of the ecosystem (Petry et al 2011), with benefit to higher trophic levels, such as aquatic insects (Lopes et al 2016), which explains the seasonal variation in the diet of the species of the present study.

Several studies on the feeding of Characidae species have indicated a strong seasonal influence on the diet of these fish species in environments dammed mainly in the semiarid regions of the Brazilian northeast (Aranha, Gomes, Fogaça; Esteves and Pinto-Lobo 2001; Mazzoni and Rezende 2003; Mendes et al 2011; Ferreira 2012; Medeiros et al 2014; Lopes et al 2016; Fiori et al 2016; Oliveira et al 2016a; Oliveira et al 2018).

A

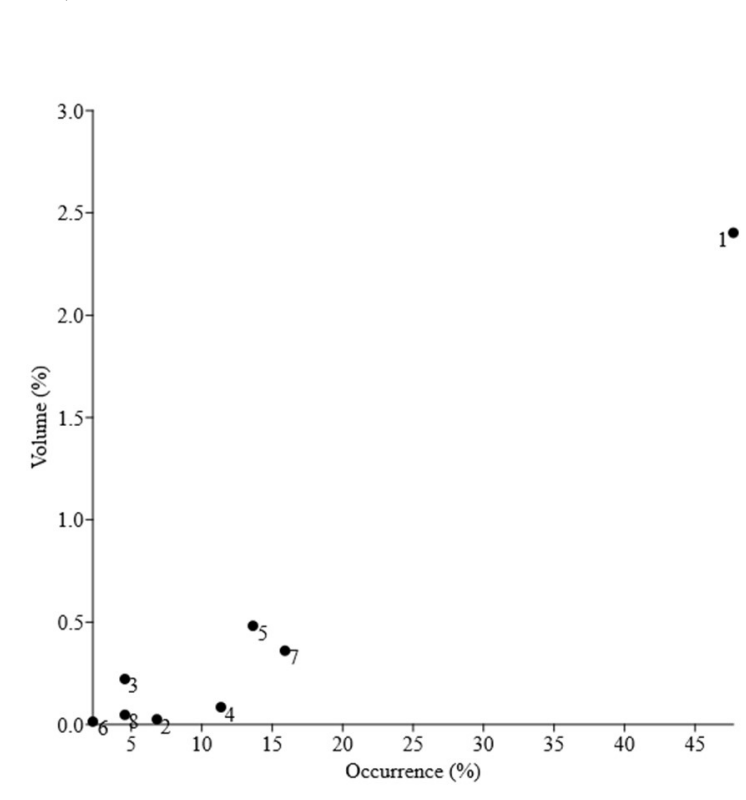

In the present study Astyanax aff. bimaculatus was classified as insectivorous but showed seasonal changes in the consumption of insect orders. Its diet consisted of a predominance of Coleoptera and Diptera, as well as native and allochthonous resources, confirming that it has a somewhat flexible diet, eating a great diversity of items.

Species belonging to the genus Astyanax are known to be highly flexible in their diets, ingesting a large variety of food items, with insects and plant material being the most important resources in their diet (Esteves and Galetti Junior 1995; Andrian et al 2001; Wantzen et al 2002; Vilella et al 2002; Dias et al 2005; Gurgel et al 2005; Manna et al 2012; Teixeira 2015; Oliveira et al 2016a; Oliveira et al 2018).

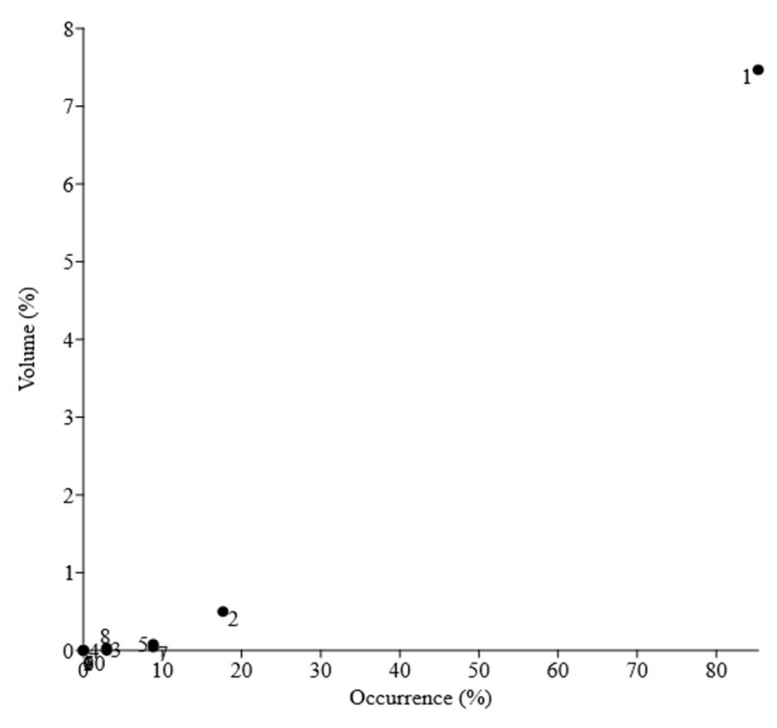

$\mathrm{B}$

Figure 3 Frequency of occurrence and volume of food resources used by (A) Astyanax aff. bimaculatus and (B) Triportheus signatus in the Umari reservoir, Rio Grande do Norte, Brazil, between February and November 2013 (1, insects; 2, shrimp; 3, other invertebrates; 4, fish scale; 5 , organic material digested; 6 , detritus/sediment; 7, plant; 8 , mollusk; 9, protozoan; 10, microalgae; 11, microcrustaceans).

Astyanax aff. bimaculatus (Linnaeus, 1758)

Recent studies with $A$. aff. bimaculatus in the Pau dos Ferros reservoir, located in Rio Grande do Norte, found insects to be the food item most consumed by this species, leading to its classification as insectivorous (Oliveira et al 2016a). In the Cuiabá River and the Chacororé lagoon, in the upper Pantanal region of Mato Grosso, Brazil, species of Astyanax spp. consumed a significantly large proportion of insects in their diet and were classified as insectivorous (Corrêa, Albrecht and Hahn 2011). Therefore, these findings indicate that these species exhibit high trophic plasticity, with an ability to explore varied resources according to their availability in the environment, and can, therefore, be considered generalists and opportunistic (Teixeira 2015). According to Teixeira (2015), the generalist ecophysiological habits of these species is probably related to their oral apparatus, digestive tract and behavior.

Triportheus signatus (Garman, 1890)

Species of the Triportheidae family have a characteristic feeding habit, mainly consuming insects and plant remains (Gama and Caramaschi 2001; Galina and Hahn 2004). In the Salto Grande reservoir, São Paulo, T. signatus 
had a diet consisting primarily of insects and secondarily crustaceans (Höflinget et al 2000). In the Sobradinho reservoir (Pinto et al 2011), as well as in the Santa Cruz reservoir (Oliveira et al 2016b) located in the semiarid region of Rio Grande do Norte, this species consumed insects preferentially and was identified as insectivorous.

On the Seridó River, located in the state of Paraíba, this species had a very varied diet, but was based mainly on insects followed by plant material (Mendes et al 2011). It was described by the authors as omnivorous and generalist, with a tendency towards insectivorous. Similarly, in the Seridó River, Rio Grande do Norte, this species consumed predominantly insects and plant remnants (Silva 2012b).

The feeding habits of Triportheus signatus found in the present study corroborate the previously mentioned studies, with the diet found to be composed of different alimentary resources with insects as a primary item. Over time, the consumption of the items demonstrated that this species has a generalist habit.

Insects represent the largest group in the animal kingdom, with a high concentration of colonization in the aquatic environment, making these organisms a food source for many trophic guilds (Vidotto-Magnoni and Carvalho 2009) and especially for insectivorous species such as $A$. aff. bimaculatus and $T$. signatus. However, there is temporal variation in the abundance of these insects, especially among the orders, as observed in the present study. This variation can be attributed to the fact that some orders of insects benefit from their reproductive processes occurring during short flood years (Cunico et al 2002). However, several species of insects do not have strong environmental restrictions, predominating in aquatic environments even during the dry season, and their colonization, therefore, is not limited (Ximenes et al 2011).

\section{Conclusions}

The species Astyanax aff. bimaculatus and Triportheus signatus consumed insects as the main item in their diets. However, there were seasonal changes in their diets, especially in the consumption of different insect orders throughout the sampling period. This finding demonstrates that these species exhibit feeding flexibility, using resources that are most abundant and available in environment. Therefore, the seasonal changes observed in the diet of the species of our study were possibly influenced by the pluviometric oscillations and the water volume of the reservoir since the reservoir volume increases during the rainy season and consequently increases the availability of terrestrial invertebrates (allochthonous resources) especially insects. The opposite occurred in the dry season, with a greater prevalence of autochthonous items found in the diet.

\section{Acknowledgments}

We thank the Conselho Nacional de Desenvolvimento Científico e Tecnológico (CNPq), the Coordenação de Aperfeiçoamento de Pessoal de Nível Superior (CAPES) and the Fundação de Apoio à Pesquisa do Estado do Rio Grande do Norte (FAPERN) for financial support. We thank the Laboratório de Ictiologia (LABIC) da Universidade do Estado do Rio Grande do Norte (UERN) and the Laboratório de Ecologia de Peixes e Pesca Continental (LEPPEC) of the Universidade Federal Rural do Semi-Árido (UFERSA) for logistic support.

\section{References}

Abelha MCF, Agostinho AA, Goulart E (2001) Plasticidade trófica em peixes de água doce. Acta Scientiarum 23:425-434.

Andrian IF et al (2001) Dieta de Astyanax bimaculatus (Linnaeus, 1758) (Characiformes, Characidae), da área de influência do reservatório de Corumbá, Estado de Goiás, Brasil. Acta Scientiarum $23: 435-440$

Aranha JMR, Gomes JHC, Fogaça FNO (2000) Feeding of two sympatric species of Characidium, C. lanei and $\mathrm{C}$. pterostictum (Characidiinae) in a coastal stream of Atlantic Forest (Southern Brazil). Brazilian Archives of Biology and Technology 43:527-531.

Bonato KO, Delariva RL, Silva JC (2012) Diet and trophic guilds of fish assemblages in two streams with different anthropic impacts in the northwest of Paraná, Brazil. Zoologia 29:27-38.

Corrêa CE, Albrecht MP, Hahn NS (2011) Patterns of niche breadth and feeding overlap of the fish fauna in the seasonal Brazilian Pantanal, Cuiabá River basin. Neotropical Ichthyology 9:637-646.

Costello MJ (1990) Predador feeding strategy and prey importance: a new graphical analysis. Journal of Fish Biology 36:261-263.

Esteves KE, Galetti Junior PM (1995) Food partitioning among some characids of a small Brazilian floodplain lake from the Parana River basin. Environmental Biology of Fishes 45:375-389.

Esteves KE, Pinto-Lobo AV (2001) Feeding pattern of Salminus maxillosus (Pisces, Characidae) at Cachoeira das Emas, Mogi-Guaçu River (São Paulo state, southeastern Brazil). Brazilian Journal of Biology 61:267-276.

Galina AB, Hahn NS (2001) Atividade de forrageamento de Triportheus spp. (Characidae, Triportheinae) utilizada como ferramenta de amostragem da Entomofauna, na área do reservatório de Manso, MT. Revista Brasileira de Zoociências 6:81-92.

Gama CS, Caramaschi EP (2001) Alimentação de Triportheus albus (Cope 1971) (Osteichthyes, Characiformes) face à implantação do AHE Serra da Mesa no rio Tocantins. Revista Brasileira de Zoociências 3:159-170.

Gurgel HCB, Canan B (1999) Feeding of six fish species in Jiqui Lagoon, eastern coast of Rio Grande do Norte, Brazil. Acta Scientiarum. Biological Sciences 21:243-246.

Gurgel HCB, Lucas FD, Souza LLG (2002) Dieta de sete espécies de peixes do semi-árido do Rio Grande do Norte, Brasil. Revista de Ictiologia 10:7.

Hammer O (2018) PAST - Palaeontological Statistics, version 3.15. http://folk.uio.no/ohammer/past/. Accessed on: May 20, 2017.

Hellawell JM, Abel R (1971) A rapid volumetric method for the analysis of the food of fishes. Journal of Fish Biology 3: 29-37. 
Hynes HBN (1950) The food of freshwater sticklebacks (Gasterosteus aculeatus and Pygosteus pungitius) with a review of methods used in studies of the food of fishes. Journal of Animal Ecology 19:36-58.

Hyslop EJ (1980) Stomach contentes analysis - a review of methods and their application. Journal Fish Biology 17:411-429.

Kawakami E, VAZZOLER G (1980) Método gráfico e estimativa de índice alimentar aplicado no estudo de alimentação de peixes. Boletim do Instituto Oceanográfico 29:205-207.

Mazzoni R, Rezende CF (2003) Seasonal diet shift in a Tetragonopterinae (Osteichthyes, Characidae) from Ubatiba River, RJ, Brazil. Brazilian Journal of Biology 63:69-74.

McCafferty WP (1981) Aquatic entomology: the fishermen's and ecologist's illustrated guide to insects and their relatives. Boston: Jones and Bartlett Publishers.

Mendes LB et al (2011) Food habits of Triportheus signatus (Teleostei, Characidae) in a Brazilian semi-arid intermittent river. Revista Brasileira de Zoociências 13:59-73.

Merritt RW, Cummins KW (1996). An introduction to the aquatic insects of North America. Dubuque, Kendall/Hunt.

Montenegro AKA, Torelli JER, Marinho RSA, Crispim MC, Hernandez MIM (2010) Aspects of the feeding and population structure of Leporinus piau (Fowler, 1941) (Actinopterygii, Characiformes, Anostomidae) of Taperoá II Dam, semi-arid region of Paraíba, Brazil. Biotemas 23:101-110.

Montenegro LA, Damasceno DNF, Almeida RG, Chellappa S (2011) Biologia alimentar do mussum, Synbranchus marmoratus (Bloch, 1795) (Osteichthyes: Synbranchidae) no açude Marechal Dutra localizado no semi-árido brasileiro. Biota Amazônia 1:52-60.

Needham JG, Needham PR (1982). Guia para el estudio de los seres vivos de las aguas dulces. Barcelona: Reverté S.A.

Oliveira G (2012) Conhecimento Ecológico Tradicional e Dieta Alimentar de Peixes no Sistema de Baía Caiçara no Rio Paraguai, Cáceres, Pantanal de Mato Grosso, MT, Brasil. Dissertation, Universidade do Estado de Mato Grosso.

Oliveira JF, Costa RS, Novaes JLC, Rebouças LGF, Morais-Segundo ALN, Peretti D (2016a) Efeito da seca e variação espacial na abundância de indivíduos nas guildas tróficas em um reservatório do semiárido brasileiro. Boletim do Instituto de Pesca 42:51-64

Oliveira JF, Morais-Segundo ALN, Novaes JLC, Costa RS, França JS, Peretti D (2016b) Estrutura trófica da ictiofauna em um reservatório do semiárido brasileiro. Iheringia. Série Zoologia 106:19.

Oliveira JF, Oliveira JCD, Nascimento L, Fernandes RTV, Novaes JLC, Peretti D (2018) Feeding patterns, trophic structure and damming rivers effect: studies applied in freshwater environments in the Brazilian semi-arid region. Journal of Animal Behaviour and Biometeorology 6:41-47.

Pessoa EKR, Silva NB, Araújo A, Chellappa S (2012) Morphohistology of the digestive tract of the carnivorous fish Hoplias malabaricus (Bloch, 1794) (Osteichthyes: Erythrinidae). Animal Biology Journal 3:145-158.

Pouilly M, Yunoki T, Rosales C, Torres L (2004) Trophic structure of fish assemblages from Mamoré river floodplain lakes (Bolivia). Ecology of Freshwater Fish 13:245-257.

Rosecchi E, Nouaze Y (1987) Comparaison de cinq índices alimentaires utilisés dans I'analyse des contenus stomacaus. Revista Trav. Int. de Peches Marit 49:111-123.
Santos NCL, Medeiros TN, Alrocha AAF, Dias RM, Severi W (2014) Uso de recursos alimentares por Plagioscion squamosissimus - piscívoro não-nativo no Reservatório de Sobradinho-BA, Brasil. Boletim Instituto de Pesca 40:397-408.

SEMARH - Secretária de Recursos Hídricos e Meio Ambiente do Estado do Rio Grande do Norte (2013). http://www.semarh.rn.gov.br/. Accessed on: May 20, 2017.

Silva DA, Pessoa EKR, Costa SAGL, Chellappa NT, Chellappa S (2012a) Ecologia alimentar de Astyanax lacustris (Osteichthyes: Characidae) na Lagoa do Piató, Assú, Rio Grande do Norte, Brasil. Biota Amazônia 2:74-82.

Silva MJ (2012b) Ecologia Trófica da Assembleia de peixes em um rio intermitente do semiárido. Dissertation, Universidade Estadual da Paraíba.

Silva MJ et al (2010) Food resources used by three species of fish in the semi-arid region of Brazil. Neotropical Ichthyology 8:819-825.

Teixeira FK (2015) Ictiofauna da Bacia do Rio Mundaú, Dieta e Morfologia do Trato Digestório de Cinco Espécies da Família Characidae (Actinopterygii: Characiformes). Dissertation, Universidade Federal do Ceará.

Zavala-Camin LA (1996) Introdução aos estudos sobre alimentação natural em peixes. Maringá: Editora da Universidade Estadual de Maringá. 